In the laboratory $5 \mathrm{~g}$ of soil is weighed, transferred to a stout $50-\mathrm{ml}$ roundbottomed centrifuge tube, and shaken with enough water to fill the tube to within about $2.5 \mathrm{~cm}$ from the brim. The tube is then centrifuged at 2000 rpm for one minute. The supernatant is poured away and the process repeated. Zinc sulphate solution of specific gravity $1.180\left(33^{\circ}\right)$ is then added until the tube requires about $1 \mathrm{ml}$ to fill it completely. The tube and zinc sulphate solution are shaken and allowed to stand for 10 minutes. Using a plastic syringe and disposable needle the clear supernatant is then withdrawn from the tube and passed through a Millipore filter pad of pore size $14.0 \mu \mathrm{m}$ (Millipore Corporation, Catalogue number NC WP 02500). The filter pad is held in a Millipore Swinnex 25 syringe attachment, and after filtration the pad is removed, mounted on a microscopic slide, and any ova present are counted. The count represents those present in the $5 \mathrm{~g}$ sample of soil.

Borg, O A, and Woodruff, A W, British Medical fournal, 1973, 4, 470.

Department of Clinical Tropical Medicine, London School of Hygiene and Tropical Medicine and Medical Unit, Hospital for Tropical Diseases, London

A W WOODRUFF, MD, FRCP, director

A I SHAH, BSC, FIMLT, technician

\section{Time course of changes in concentration of some plasma components after frusemide}

Spontaneous diurnal variations in the concentration of plasma constituents are mostly small or difficult to assess in the supine position ${ }^{1}$ and are without consistent pattern. Change in position may, however, greatly influence the plasma concentrations, particularly of nondiffusible ions ${ }^{2}$ but also of some diffusible ones, ${ }^{2}$ as may meals ${ }^{13}$ and exercise. ${ }^{13}$ Potent short-acting diuretics may disturb these normally small variations, influencing many important physiological processes governing homoeostasis-such as diuresis, urinary excretion of electrolytes, plasma volume,${ }^{4}$ and general haemodynamic ${ }^{4}{ }^{5}$ and hormonal balance-especially in the renin-angiotensin-aldosterone system. ${ }^{4} \mathrm{We}$ report changes in some plasma concentrations after frusemide administration.

\section{Methods and results}

Two healthy people and five ambulant hospital patients volunteered for the experiments. One patient had aortic incompetence, two aortic stenosis, one coronary heart disease, and one pulmonary emphysema. Three of the patients were on long-term diuretic treatment until two days before the experiment. The previous day and throughout the day of the experiment everyone received a low-salt diet and was instructed to avoid foods rich in potassium (according to a list). Fluid intake was not restricted. Physical activity was kept to a minimum.

Special care was taken with blood sampling. ${ }^{2}{ }^{3}$ Samples were taken from an antecubital vein through an indwelling Teflon catheter, which was kept clear by intermittent flushing with small amounts of heparinised isotonic saline. The first portion of each sample was discarded. The tubes were centrifuged at $2000 \mathrm{rpm}$ for 15 minutes and the plasma was separated and recentrifuged for five minutes and then stored in sealed containers before analysis in one batch next morning. The following were measured: packed cell volume (in duplicate), total protein, sodium, potassium, chloride, calcium, magnesium, inorganic phosphorus, urea, creatinine, and urate. Baseline samples were taken at 9 am, then everyone was given $80 \mathrm{mg}$ frusemide by mouth. Samples were withdrawn after $1,3,5,8$, and 24 hours, the volunteers having been recumbent for half an hour before sampling to ensure plasma volume equilibrium. Differences between the mean baseline values and mean values after frusemide were assessed by Student's $t$ test on paired observations.

No significant changes in the mean concentrations of sodium, calcium, or magnesium were observed. The figure gives values that did change sig-
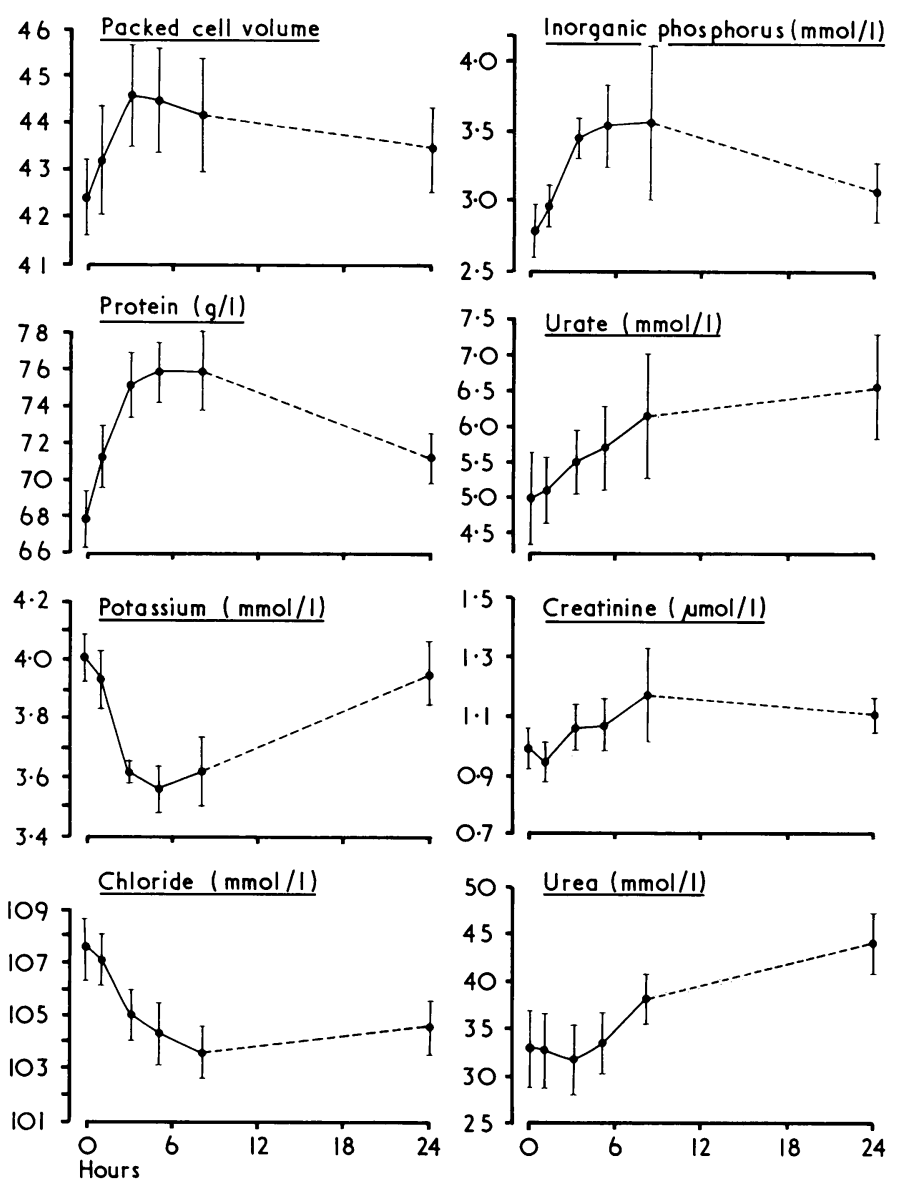

Changes in packed cell volume and in plasma concentrations of protein, potassium, chloride, inorganic phosphorus, urate, creatinine, and urea after administration of frusemide $80 \mathrm{mg}$ by mouth (at time 0 ). Values are means $\pm S E$ of mean.

Conversion: $S I$ to traditional units-Potassium: $1 \mathrm{mmol} / 1=1 \mathrm{mEq} / 1$. Chloride: $1 \mathrm{mmol} / 1=1 \mathrm{mEq} / 1$. Inorganic phosphorus: $1 \mathrm{mmol} / 1 \approx 3.1 \mathrm{mg} /$ $100 \mathrm{ml}$. Urate: $1 \mathrm{mmol} / 1 \approx 16.8 \mathrm{mg} / 100 \mathrm{ml}$. Creatinine: $1 \mu \mathrm{nol} / 1 \approx 0.0113$ $\mathrm{mg} / 100 \mathrm{ml}$. Urea: $1 \mathrm{mmol} / \mathrm{l} \approx 6.0 \mathrm{mg} / 100 \mathrm{ml}$.

nificantly, the mean concentration of each constituent \pm SE of the mean being related to time.

\section{Comment}

These observations show that frusemide causes acute changes in the levels of several plasma components and should be considered in any assessment of electrolyte disturbances. Different diuretics probably all have their own characteristic plasma concentration/time relationship.

${ }^{1}$ Fawcett, J K, and Wynn, V, British Medical fournal, 1956, 2, 582.

2 Statland, B E, Bokelund, H, and Winkel, P, Clinical Chemistry, 1.974, 20, 1513.

${ }^{3}$ Statland, B E, Winkel, P, and Bokelund, H, Clinical Chemistry, 1973, 19, 1380.

4 Rosenthal, J, et al, Canadian fournal of Physiology and Pharmacology, 1968, 46, 85.

5 Lal, S, et al, British Heart fournal, 1969, 31, 711.

Institute for Respiratory Physiology, University of Oslo, Ullevål Hospital, Oslo 1, Norway

TORE O HAUG, $M D$, senior registrar 